\title{
NMR resonance assignments of the FinO-domain of the RNA chaperone RocC
}

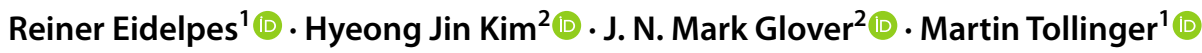

Received: 30 August 2020 / Accepted: 31 October 2020 / Published online: 11 November 2020

(c) The Author(s) 2020

\begin{abstract}
In prokaryotic species, gene expression is commonly regulated by small, non-coding RNAs (sRNAs). In the gram-negative bacterium Legionella pneumophila, the regulatory, trans-acting sRNA molecule RocR base pairs with a complementary sequence in the 5'-untranslated region of mRNAs encoding for proteins in the bacterial DNA uptake system, thereby controlling natural competence. Sense-antisense duplexing of RocR with targeted mRNAs is mediated by the recently described RNA chaperone RocC. RocC contains a $12 \mathrm{kDa}$ FinO-domain, which acts as sRNA binding platform, along with an extended C-terminal segment that is predicted to be mostly disordered but appears to be required for repression of bacterial competence. In this work we assigned backbone and side chain ${ }^{1} \mathrm{H},{ }^{13} \mathrm{C}$, and ${ }^{15} \mathrm{~N}$ chemical shifts of RocC's FinO-domain by solution NMR spectroscopy. The chemical shift data for this protein indicate a mixed $\alpha / \beta$ fold that is reminiscent of FinO from Escherichia coli. Our NMR resonance assignments provide the basis for a comprehensive analysis of RocC's chaperoning mechanism on a structural level.
\end{abstract}

Keywords NMR resonance assignment $\cdot$ Protein $\cdot$ Ribonucleic acid $\cdot$ Chaperone $\cdot$ Base-pairing

\section{Biological context}

The formation of molecular interactions in RNA-based regulatory processes often requires chaperoning by proteins (Woodson et al. 2018). In prokaryotic species, RNA chaperones play a particularly critical role in the regulation of gene expression. The protein RocC (repressor of competence chaperone) from the bacterium Legionella pneumophila, which is involved in post-transcriptional gene regulation, is such an RNA chaperone (Attaiech et al. 2016). RocC specifically binds to a non-coding 66-nucleotide RNA molecule, RocR, which in turn recognizes and binds to the 5'-untranslated region of mRNAs that encode for a variety of proteins in the bacterial DNA uptake system, such as

\footnotetext{
J. N. Mark Glover

mglover@ualberta.ca

Martin Tollinger

martin.tollinger@uibk.ac.at

1 Institute of Organic Chemistry, Center for Molecular Biosciences Innsbruck (CMBI), University of Innsbruck, Innrain 80/82, 6020 Innsbruck, Austria
}

2 Department of Biochemistry, University of Alberta, T6G 2H7 Edmonton, AB, Canada
ComEA, ComEC and ComF, controlling their expression (Attaiech et al. 2016). Within this scheme, RocC acts as an RNA chaperone by promoting strand exchange and intermolecular base pairing between the regulatory sRNA molecule RocR and its target mRNAs. Intriguingly, RocC binds to a polyU overhang at the 3'-tail of RocR, while sense-antisense base pairing occurs in a stem loop at the 5'-end of RocR, which contains a 6-nucleotide antisense sequence that binds to the complementary "RocR-box" in mRNAs. In addition, RocC binding appears to protect RocR from degradation and maintain its steady-state level. Mechanistic details of how exactly RocC enhances the formation of intermolecular base pairs and stabilizes RocR are not known to date.

$\mathrm{RocC}$ is a member of the FinO family of RNA chaperones, which is widespread throughout bacterial species (Attaiech et al. 2017; Glover et al. 2015; Olejniczak and Storz 2017). Despite their common occurrence, high-resolution structural data of FinO proteins are relatively rare (Chaulk et al. 2010; Ghetu et al. 2000; Gonzalez et al. 2017). The crystal structure of FinO from E. coli in the absence of RNA revealed a mixed $\alpha / \beta$ fold, where five helices $\alpha 2-\alpha 6$ pack together with four short antiparallel $\beta$-strands ( $\beta 1-\beta 4)$ to form a compact protein core, while an extended $\mathrm{N}$-terminal helix $\alpha 1$ protrudes into the surrounding solvent (Ghetu et al. 2000). Two 
charged patches of positively charged residues in FinO were identified as likely RNA binding sites near the N-terminal end of helix $\alpha 1$ and on the surface of the central protein core, respectively. By combining protein-RNA crosslinking data with fluorescence resonance energy transfer, FRET (Ghetu et al. 2002), and small-angle X-ray scattering, SAXS, a low-resolution model for RNA binding to FinO from $E$. coli reconciling these data was derived (Arthur et al. 2011). In spite of this work, the structural mechanism by which these chaperones bind their RNAs and carry out their chaperone activities are poorly understood.

Here we present the solution NMR backbone and sidechain assignments of the FinO-domain of the RNA chaperone RocC. RocC from L. pneumophila and FinO from E. coli share a sequence identity of $29.1 \%$. Major structural differences between these two chaperones include an an extended C-terminal segment spanning ca. 100 residues (127-230) in $\mathrm{RocC}$, which is predicted to be mostly disordered but appears to be required for function. RocC's FinO-domain, which is studied in this work, is located between residues 24 and 126 and acts as the major sRNA binding platform in this chaperone.

\section{Methods and experiments}

\section{Sample preparation}

Transformation of codon-optimized plasmids of RocC residues 24-126 from the bacterium Legionella pneumophila (GenBank protein code CAH11296.1), cloned in the expression vector pGEX-6P-1 containing an N-terminal GST tag, was conducted in the E. coli strain BL21(DE3). A $100 \mathrm{~mL}$ culture of Luria Bertani (LB) medium with $100 \mu \mathrm{g} / \mathrm{mL}$ ampicillin was inoculated with one bacterial colony and incubated overnight at $37{ }^{\circ} \mathrm{C}$ and $200 \mathrm{rpm}$. A portion of the overnight culture was centrifuged at $2000 \times g$ and resuspended in $1 \mathrm{~L}$ of $\mathrm{M} 9$ minimal medium (containing $1 \mathrm{~g} / \mathrm{L}$ ${ }^{15} \mathrm{NH}_{4} \mathrm{Cl}$ or $3 \mathrm{~g} / \mathrm{L}{ }^{13} \mathrm{C}_{6}$-D-glucose and $1 \mathrm{~g} / \mathrm{L}^{15} \mathrm{NH}_{4} \mathrm{Cl}$, both Cambridge Isotope Laboratories, and $100 \mu \mathrm{g} / \mathrm{mL}$ ampicillin) to yield a cell density of 0.1 . The culture was incubated at $37{ }^{\circ} \mathrm{C}$ and $200 \mathrm{rpm}$ until the cell density reached $0.5-0.6$ (at $600 \mathrm{~nm}$ ). One hour prior to induction the temperature was lowered to $18{ }^{\circ} \mathrm{C}$. Protein expression was induced by addition of isopropyl- $\beta$-D-1-thiogalactopyranoside (IPTG, $300 \mathrm{mM}$ ) overnight. Cells were harvested at $3440 \times g$ and $4{ }^{\circ} \mathrm{C}$ for $40 \mathrm{~min}$ and stored at $-20{ }^{\circ} \mathrm{C}$ until use. The pellets of $1 \mathrm{~L}$ expression medium were thawed and resuspended in $100 \mathrm{~mL}$ of a buffer containing $50 \mathrm{mM}$ HEPES $\mathrm{pH}$ 7.3,
$500 \mathrm{mM} \mathrm{NaCl}$ and $5 \%$ glycerol. After the addition of $200 \mu \mathrm{L}$ protease inhibitor cocktail His-tag (Carl Roth) per $100 \mathrm{~mL}$ suspension, the cells were passed through a French Press and centrifuged at $15,000 \times g$ and $4{ }^{\circ} \mathrm{C}$ for 1 hour. The cleared lysate was loaded onto a GST affinity column (GST Trap FF $5 \mathrm{~mL}$, GE Healthcare) and $\mathrm{RocC}_{24-126}$ was eluted with $20 \mathrm{mM}$ glutathione in the same buffer at a flow rate of $2 \mathrm{~mL} /$ min. RocC $_{24-126}$ containing fractions were collected and the buffer was exchanged by concentrating the sample four times to ca. $2 \mathrm{ml}$ by centrifugation (Amicon Ultra $3 \mathrm{kDa}$ MWCO, Merck Millipore) and refilling the tube to $7.5 \mathrm{~mL}$ with buffer containing $25 \mathrm{mM}$ HEPES pH 7.3, $150 \mathrm{mM} \mathrm{NaCl}$. Removal of the GST affinity tag was performed with PreScission protease (GE Healthcare). The sample was incubated with 40 units of protease and shaked gently on a nutator at $4{ }^{\circ} \mathrm{C}$ overnight. For the final purification step the protein sample was loaded onto a size exclusion column (HiLoad 16/600 Superdex 75 prep grade, GE Healthcare) and eluted isocratically at $1 \mathrm{~mL} / \mathrm{min}, 4^{\circ} \mathrm{C}$ with $25 \mathrm{mM}$ HEPES pH 7.3 buffer containing $150 \mathrm{mM} \mathrm{NaCl}$. All purification steps were monitored by SDS-PAGE gel electrophoresis with $15 \%$ gels. $\mathrm{RocC}_{24-126}$ samples were supplemented with $10 \% \mathrm{D}_{2} \mathrm{O}(\mathrm{v} / \mathrm{v})$ for NMR spectroscopy, with concentrations of $0.2-0.5 \mathrm{mM}$ for ${ }^{15} \mathrm{~N}$ labeled and ${ }^{15} \mathrm{~N} /{ }^{13} \mathrm{C}$ labeled protein. Mass spectrometry of unlabeled $\mathrm{RocC}_{24-126}$ confirmed the integrity of the protein.

\section{NMR spectroscopy}

NMR spectra were recorded at $25^{\circ} \mathrm{C}$ on a $700 \mathrm{MHz}$ Bruker Avance Neo spectrometer equipped with room temperature or cryogenically cooled probes and a $500 \mathrm{MHz}$ Agilent DirectDrive 2 spectrometer equipped with a room temperature probe. Backbone resonance assignments of $\mathrm{RocC}_{24-126}$ were performed using a two-dimensional ${ }^{1} \mathrm{H}-{ }^{15} \mathrm{~N}-\mathrm{HSQC}$ and three-dimensional $\mathrm{HNCACB}, \mathrm{CBCA}(\mathrm{CO}) \mathrm{NH}$, and $\mathrm{HNCO}$ experiments. A two-dimensional ${ }^{1} \mathrm{H}_{-}{ }^{13} \mathrm{C}-\mathrm{HSQC}$ and three-dimensional (H)CC(CO)NH-TOCSY, H(CCO)NHTOCSY, ${ }^{1} \mathrm{H}-{ }^{15} \mathrm{~N}$-TOCSY-HSQC,${ }^{1} \mathrm{H}-{ }^{15} \mathrm{~N}$-NOESY-HSQC, and ${ }^{1} \mathrm{H}_{-}{ }^{13} \mathrm{C}-\mathrm{NOESY}-\mathrm{HSQC}$ experiments were used for sidechain assignments (Sattler et al. 1999). Data processing was performed with NMRPipe (Delaglio et al. 1995) and the CcpNMR software package was used for resonance assignment (Vranken et al. 2005).

\section{Assignments and data deposition}

The ${ }^{1} \mathrm{H}_{-}{ }^{15} \mathrm{~N}-\mathrm{HSQC}$ spectrum of $\mathrm{RocC}_{24-126}$ (Fig. 1) shows that backbone amide resonances are well dispersed, as expected for a folded protein. We obtained assignment of 


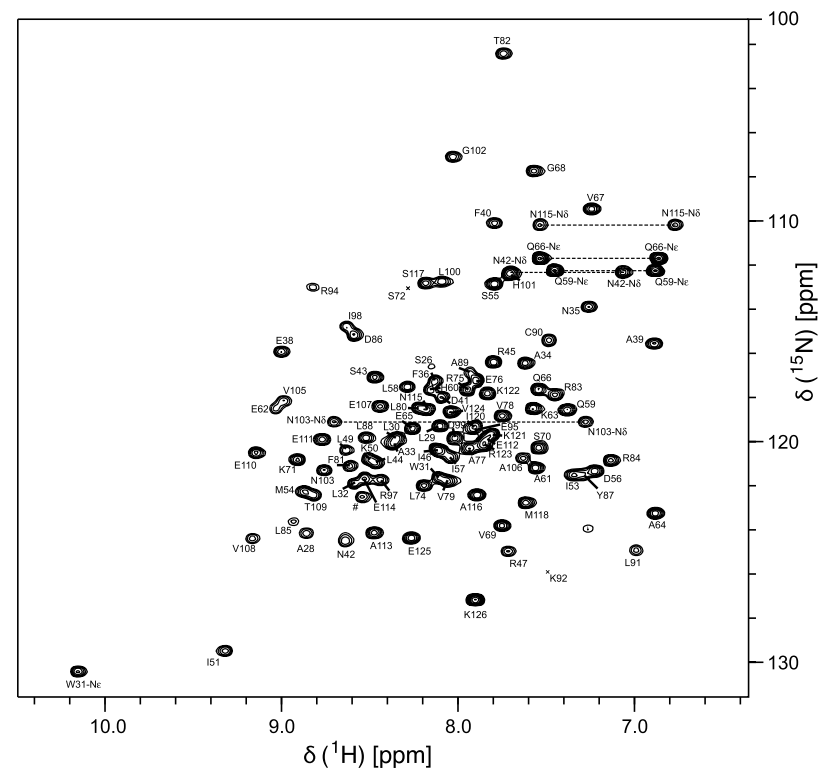

Fig. $1700 \mathrm{MHz}{ }^{1} \mathrm{H}^{15} \mathrm{~N}-\mathrm{HSQC}$ spectrum of RocC (residues 24-126) in $25 \mathrm{mM}$ HEPES buffer, $\mathrm{pH} 7.3,150 \mathrm{mM} \mathrm{NaCl}$, supplemented with $10 \% \mathrm{D}_{2} \mathrm{O}$ at $25{ }^{\circ} \mathrm{C}$. Resonance assignments are shown using single letter codes and horizontal lines indicate asparagine and glutamine $\mathrm{NH}_{2}$ side-chain resonances. Asterisks are used to mark positions of residues below the intensity cut-off and hashtags indicate resonances deriving from the N-terminal PreScission cleavage site. Resonance assignments are available online at the BMRB repository (accession number 50404)

the backbone amide resonances for 92 of 100 non-proline residues in $\mathrm{RocC}_{24-126}$. For a number of residues at the $\mathrm{N}$-terminus of the protein (Ala24, Arg25, Asp27), as well as Gly52, Lys73, Ala93, Val96 and Lys119, assignmens of backbone amide resonances were not obtained. Backbone $\mathrm{C}^{\alpha}$ and carbonyl C' resonances were assigned for 102 and 93 out of 103 residues, corresponding to $99 \%$ and $90 \%$ completeness, respectively. Side-chain $\mathrm{C}^{\beta}, \mathrm{C}^{\gamma}$ and $\mathrm{C}^{\delta}$ resonance assignments are $99 \%, 78 \%$ and $78 \%$ complete, while ${ }^{1} \mathrm{H}$ resonances could be assigned for $92.9 \%$ of $\mathrm{H}^{\alpha}$ nuclei along with $42.9 \%, 22.7 \%$ and $23.3 \%$ of aliphatic side-chain $\mathrm{H}^{\beta}, \mathrm{H}^{\gamma}$ and $\mathrm{H}^{\delta}$ resonances, respectively. Assignments of the side-chain amides $\left({ }^{1} \mathrm{H}\right.$ and $\left.{ }^{15} \mathrm{~N}\right)$ were obtained for three asparagines and both glutamines.

Based on the $\mathrm{H}^{\mathrm{N}}, \mathrm{N}, \mathrm{C}^{\prime}, \mathrm{C}^{\alpha}$ and $\mathrm{C}^{\beta}$ chemical shifts, the TALOS + software (Shen et al. 2009) was used to predict the secondary structure elements of $\mathrm{RocC}_{24-126}$ (Fig. 2). These data indicate the presence of a mixed $\alpha / \beta$ fold, in accordance with FinO from E. coli (Ghetu et al. 2000) and the ProQ homolog Lpp 1663 from Legionella pneumophila (Immer et al. 2018). At least three short $\beta$-strands are present in $\mathrm{RocC}_{24-126}$, along with four $\alpha$-helices of five or more amino acid residues in length. For the central helix between residues Ile53 and Gln66 the NMR chemical shift data indicate a possible break or kink around position 60. In addition, moderate propensities for local helix-like conformation exist for residues Arg94 and Glu95, as well as for alanine at position 39. For Ala39, however, the probability to have local helical geometry barely exceeds $50 \%$, while the probability for a local loop structure is just below this threshold.

The NMR chemical shift assignments of $\mathrm{RocC}_{24-126}$ have been deposited at the Biological Magnetic Resonance Data Bank (http://www.bmrb.wisc.edu) with the BMRB accession number 50404. These data will enable us to characterize mechanistic details of the RocC-RocR chaperoning system in future studies.

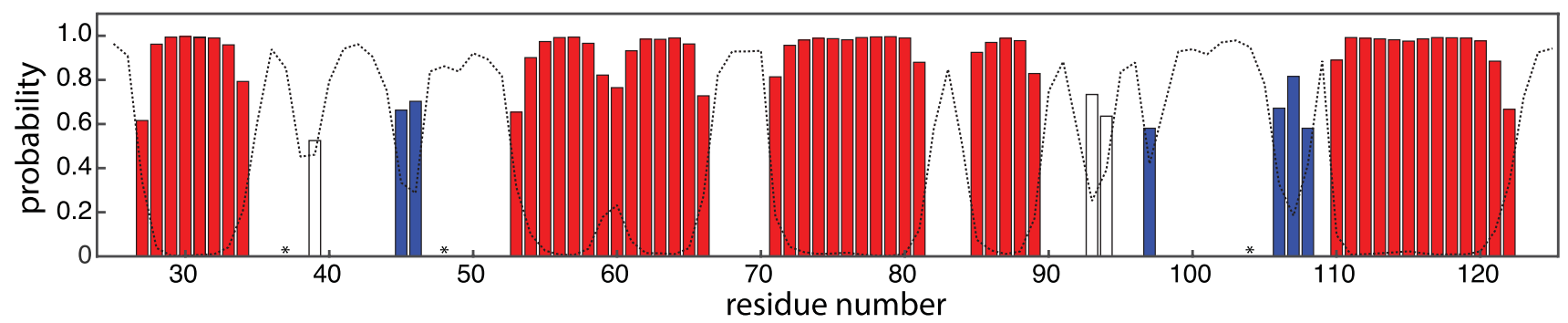

Fig. 2 Secondary structure of RocC (residues 24-126) as predicted by TALOS+, based on backbone $\mathrm{H}^{\mathrm{N}}, \mathrm{N}, \mathrm{C}^{\prime}, \mathrm{C}^{\alpha}$ and $\mathrm{C}^{\beta}$ chemical shifts. Secondary structure probabilities are shown as bars (red, $\alpha$-helices; blue, $\beta$-strands); short segments of helix-like backbone geometry covering up to two amino acid residues are indicated by open bars and loop probabilities are shown as dotted line (black). The positions of prolines are denoted by asterisks 
Acknowledgements This work was supported by the Austrian Science Fund FWF (P31054 and P33953) and the Austrian Research Promotion Agency FFG (project 858017, West-Austrian BioNMR). We thank Dr. Thomas Müller, University of Innsbruck, for mass spectrometry.

Funding Open access funding provided by the Austrian Science Fund (FWF).

Open Access This article is licensed under a Creative Commons Attribution 4.0 International License, which permits use, sharing, adaptation, distribution and reproduction in any medium or format, as long as you give appropriate credit to the original author(s) and the source, provide a link to the Creative Commons licence, and indicate if changes were made. The images or other third party material in this article are included in the article's Creative Commons licence, unless indicated otherwise in a credit line to the material. If material is not included in the article's Creative Commons licence and your intended use is not permitted by statutory regulation or exceeds the permitted use, you will need to obtain permission directly from the copyright holder. To view a copy of this licence, visit http://creativecommons.org/licenses/by/4.0/.

\section{References}

Arthur DC, Edwards RA, Tsutakawa S, Tainer JA, Frost LS, Glover JN (2011) Mapping interactions between the RNA chaperone FinO and its RNA targets. Nucl Acids Res 39:4450-4463. doi:https:// doi.org/10.1093/nar/gkr025

Attaiech L et al (2016) Silencing of natural transformation by an RNA chaperone and a multitarget small RNA. Proc Natl Acad Sci USA 113:8813-8818. doi:https://doi.org/10.1073/pnas.1601626113

Attaiech L, Glover JNM, Charpentier X (2017) RNA chaperones step out of Hfq's shadow. Trends Microbiol 25:247-249. doi:https:// doi.org/10.1016/j.tim.2017.01.006

Chaulk S et al (2010) N. meningitidis 1681 is a member of the FinO family of RNA chaperones. RNA Biol 7:812-819. doi:https://doi. org/10.4161/rna.7.6.13688

Delaglio F, Grzesiek S, Vuister GW, Zhu G, Pfeifer J, Bax A (1995) NMRPipe: a multidimensional spectral processing system based on UNIX pipes. J Biomol NMR 6:277-293. doi:https://doi. org/10.1007/BF00197809

Ghetu AF, Gubbins MJ, Frost LS, Glover JN (2000) Crystal structure of the bacterial conjugation repressor FinO. Nat Struct Biol 7:565-569. doi:https://doi.org/10.1038/76790

Ghetu AF, Arthur DC, Kerppola TK, Glover JN (2002) Probing FinOFinP RNA interactions by site-directed protein-RNA crosslinking and gelFRET. RNA 8:816-823. doi:https://doi.org/10.1017/s1355 838202026730

Glover JNM, Chaulk SG, Edwards RA, Arthur D, Lu J, Frost LS (2015) The FinO family of bacterial RNA chaperones. Plasmid 78:79-87. doi:https://doi.org/10.1016/j.plasmid.2014.07.003

Gonzalez GM et al (2017) Structure of the Escherichia coli ProQ RNAbinding protein. RNA 23:696-711. doi:https://doi.org/10.1261/ rna.060343.116

Immer C, Hacker C, Woehnert J (2018) NMR resonance assignments for a ProQ homolog from Legionella pneumophila. Biomol NMR Assign 12:319-322. doi:https://doi.org/10.1007/s1210 4-018-9831-6

Olejniczak M, Storz G (2017) ProQ/FinO-domain proteins: another ubiquitous family of RNA matchmakers? Mol Microbiol 104:905915. doi:https://doi.org/10.1111/mmi.13679

Sattler M, Schleucher J, Griesinger C (1999) Heteronuclear multidimensional NMR experiments for the structure determination of proteins in solution. Prog Nucl Magn Reson Spectrosc 34:93-158

Shen Y, Delaglio F, Cornilescu G, Bax A (2009) TALOS+: a hybrid method for predicting protein backbone torsion angles from NMR chemical shifts. J Biomol NMR 44:213-223. doi:https:// doi.org/10.1007/s10858-009-9333-z

Vranken WF et al (2005) The CCPN data model for NMR spectroscopy: development of a software pipeline. Proteins 59:687-696. doi:https://doi.org/10.1002/prot.20449

Woodson SA, Panja S, Santiago-Frangos A (2018) Proteins that chaperone RNA regulation. Microbiol Spectr. https://doi.org/10.1128/ microbiolspec.RWR-0026-2018

Publisher's Note Springer Nature remains neutral with regard to jurisdictional claims in published maps and institutional affiliations. 